\title{
Synthesis and Anticancer Activity of Novel Benzofurancarboxamides
}

\author{
Yuliia Matiichuk ${ }^{1(\mathbb{D})}$, Yuriy Ostapiuk ${ }^{2 \mathbb{D}}$, Taras Chaban ${ }^{1(\mathbb{D})}$, Marta Sulyma ${ }^{1 \mathbb{D}}$, Natalia Sukhodolska ${ }^{1}$ \\ (D), Vasyl Matiychuk 2,*(D) \\ 1 Danylo Halytsky Lviv National Medical University, Pekarska 69, Zip Code: 79010, Lviv, Ukraine; yulm77@ gmail.com; \\ 2 Ivan Franko National University of Lviv, 6 Kyryla and Mefodia, Lviv, Zip Code: 79005, Ukraine; y.ostapiuk@ gmail.com; \\ * Correspondence: v_matiychuk@ukr.net;
}

Scopus Author ID 6506975895

Received: 28.04.2020; Revised: 22.05.2020; Accepted: 24.05.2020; Published: 27.05.2020

\begin{abstract}
In our present work, we presented an efficient synthesis and anticancer activity evaluation of some novel benzofurancarboxamides. Our proposed approaches provide the possibility to design benzofurans diversity with a considerable chemical novelty. The synthesized substances were selected by the National Cancer Institute (NCI) Developmental Therapeutics Program for the in vitro cell line screening to investigate their anticancer activity. The compounds with significant levels of anticancer activities have been found that can be used for further optimization.
\end{abstract}

Keywords: organic synthesis; benzofurancarboxamides; NMR spectroscopy; anticancer activity.

(C) 2020 by the authors. This article is an open-access article distributed under the terms and conditions of the Creative Commons Attribution (CC BY) license (https://creativecommons.org/licenses/by/4.0/).

\section{Introduction}

The problem of finding effective low-toxic antitumor drugs is very important in modern medicine and pharmacy. According to the World Health Organization, more than 10 million new cancer patients appear annually.

The incidence of developing cancer is $27.7 \%$ for men and $18.5 \%$ for women. In recent years, pharmacotherapy of tumor pathology has been enriched with numerous new drugs that increase its effectiveness and safety [1].

However, despite significant advances in the chemotherapy of malignant tumors, many types of cancer remain incurable, and the availability of antitumor drugs is insufficient. Therefore, the search for new organic compounds with anticancer activity is an urgent problem of our time. The benzofuran derivatives have attracted many researchers due to the broad scope of their biological activity, which includes anticancer, antimicrobial, antiviral, antioxidant, anti-inflammatory, and other properties [1-5].

However, the study of benzofurancarboxamides is quite ambiguous. In particular, among this class of compounds, compounds exhibiting antimicrobial and anticancer were found [6-10]. Some of their analogues were recognized as inhibitors Sirtuin 2 [11], inosine 5'monophosphate dehydrogenase [12], matrix metallopeptidase 13 [13], ligands of adenosine A2A [14] and metabotropic glutamate 4 receptors [15].

In this article, which is the part of our researching biologically active heterocycles [1655], we described the synthesis and anticancer activities of new benzofurancarboxamides. 


\section{Materials and Methods}

\subsection{Materials.}

The reagents used in the synthesis were commercially available and of analytical grade. All solvents and reagents were used without further purification.

\subsection{Chemistry.}

All melting points were determined in an open capillary. The NMR-spectra were recorded using Varian Mercury $400(400 \mathrm{MHz})$ at $298 \mathrm{~K}$. Chemical shifts are reported as $\delta$ (ppm). Chemical shifts are reported as $\delta(\mathrm{ppm})$ relative to tetramethylsilane (TMS) as an internal standard. The coupling constant $\mathbf{J}$ is expressed in Hz. Elemental analysis was performed on a Vario MICRO cube automatic CHNS analyzer. This experimental analysis data on contents of Carbon, Hydrogen, and Nitrogen were within $\pm 0.3 \%$ of the theoretical values.

General procedure for the synthesis of benzofurancarboxamides (12-17): In $30 \mathrm{ml}$ of dry dioxane dissolved $0.01 \mathrm{~mol}$ of the chloroanhydride (1a or 1b) and $0.01 \mathrm{~mol}$ of the corresponding amine. After the complete dissolution of the mixture, $1 \mathrm{ml}$ of triethylamine is added to the solution and left for 30 minutes. The mixture formed at this stage is precipitated with water and left for $12 \mathrm{~h}$ to form a precipitate and then filtered. The resulting substances on the filter are washed with cold water and dried.

$\boldsymbol{N}$-(4-isopropylphenyl)-1-benzofuran-2-carboxamide (12a). Yield 81\%, mp 125$126^{\circ} \mathrm{C} .{ }^{1} \mathrm{H}$ NMR (400 MHz, DMSO) $\delta 10.40(\mathrm{~s}, 1 \mathrm{H}, \mathrm{NH}), 7.80$ (d, $J=7.7 \mathrm{~Hz}, 1 \mathrm{H}$, benzofuran), $7.75-7.66\left(\mathrm{~m}, 4 \mathrm{H}\right.$, benzofuran $\left.+\mathrm{C}_{6} \mathrm{H}_{4}\right), 7.48(\mathrm{t}, J=7.4 \mathrm{~Hz}, 1 \mathrm{H}$, benzofuran), $7.34(\mathrm{t}, J=7.4$ $\mathrm{Hz}, 1 \mathrm{H}$, benzofuran), $7.21\left(\mathrm{~d}, J=8.4 \mathrm{~Hz}, 2 \mathrm{H}, \mathrm{C}_{6} \mathrm{H}_{4}\right), 2.84(\mathrm{dt}, J=13.7,6.8 \mathrm{~Hz}, 1 \mathrm{H}, \mathrm{CH}), 1.18$ $\left(\mathrm{d}, \mathrm{J}=6.9 \mathrm{~Hz}, 6 \mathrm{H}, 2 \mathrm{CH}_{3}\right.$ ). Anal. Calcd. for $\mathrm{C}_{18} \mathrm{H}_{17} \mathrm{NO}_{2}: \mathrm{C}, 77.40 ; \mathrm{H}, 6.13 ; \mathrm{N}, 5.01$. Found: $\mathrm{C}$, 77.78; H, 6.08; N, 5.09 .

$\mathrm{N}$-(2-benzoylphenyl)-1-benzofuran-2-carboxamide (12b). Yield 73\%, mp 169-170 ${ }^{\circ} \mathrm{C}$. ${ }^{1} \mathrm{H}$ NMR (400 MHz, DMSO) $\delta 11.21(\mathrm{~s}, 1 \mathrm{H}, \mathrm{NH}), 8.01(\mathrm{~d}, J=7.9 \mathrm{~Hz}, 1 \mathrm{H}, \mathrm{ArH}), 7.75(\mathrm{~d}, J=$ $7.4 \mathrm{~Hz}, 1 \mathrm{H}$, benzofuran)), $7.73-7.60(\mathrm{~m}, 4 \mathrm{H}$, benzofuran $+\mathrm{ArH}), 7.60-7.54(\mathrm{~m}, 2 \mathrm{H}, \mathrm{ArH})$, $7.51-7.42(\mathrm{~m}, 4 \mathrm{H}, \mathrm{ArH}$, benzofuran $+\mathrm{ArH}), 7.30(\mathrm{dd}, J=15.4,7.7 \mathrm{~Hz}, 2 \mathrm{H}$, benzofuran + ArH). Anal. Calcd. for $\mathrm{C}_{22} \mathrm{H}_{15} \mathrm{NO}_{3}$ : C, 77.41; H, 4.43; N, 4.10. Found: C, 77.19; H, 4.36; N, 4.13 .

Methyl 2-[(1-benzofuran-2-ylcarbonyl)amino]-4-chlorobenzoate (12c). Yield 88\%, mp 133-1134 ${ }^{\circ} \mathrm{C} .{ }^{1} \mathrm{H}$ NMR (400 MHz, DMSO) $\delta 11.98(\mathrm{~s}, 1 \mathrm{H}, \mathrm{NH}), 8.68(\mathrm{~d}, J=2.0 \mathrm{~Hz}, 1 \mathrm{H}$, $\left.\mathrm{C}_{6} \mathrm{H}_{3}\right), 7.98(\mathrm{~d}, J=8.5 \mathrm{~Hz}, 1 \mathrm{H}$, benzofuran), $7.79(\mathrm{~d}, J=7.6 \mathrm{~Hz}, 1 \mathrm{H}$, benzofuran), $7.74-7.66$ (m, 2H, benzofuran+ $\left.\mathrm{C}_{6} \mathrm{H}_{3}\right), 7.50(\mathrm{t}, J=7.3 \mathrm{~Hz}, 1 \mathrm{H}$, benzofuran), $7.34(\mathrm{t}, J=7.4 \mathrm{~Hz}, 1 \mathrm{H}$, benzofuran), 7.27 (dd, $\left.J=8.5,2.0 \mathrm{~Hz}, 1 \mathrm{H}, \mathrm{C}_{6} \mathrm{H}_{3}\right), 3.90\left(\mathrm{~s}, 3 \mathrm{H}, \mathrm{CH}_{3}\right)$. Anal. Calcd. for $\mathrm{C}_{17} \mathrm{H}_{2} \mathrm{ClNO}_{4}$ : C, 61.92; H, 3.67; N, 4.25. Found: C, 61.85; H, 3.55; N, 4.33.

Methyl 2-[(1-benzofuran-2-ylcarbonyl)amino]-4,5-dimethoxybenzoate (12d). Yield 91\%, mp 147-148 ${ }^{\circ} \mathrm{C} .{ }^{1} \mathrm{H}$ NMR (400 MHz, DMSO) $\delta 12.02$ (s, $\left.1 \mathrm{H}, \mathrm{NH}\right), 8.37$ (s, $1 \mathrm{H}, \mathrm{C}_{6} \mathrm{H}_{2}$ ), 7.77 (d, $J=7.6 \mathrm{~Hz}, 1 \mathrm{H}$, benzofuran), 7.67 (d, $J=8.3 \mathrm{~Hz}, 1 \mathrm{H}$, benzofuran), 7.62 (s, 1H, benzofuran), $7.48(\mathrm{t}, J=7.5 \mathrm{~Hz}, 1 \mathrm{H}$, benzofuran), $7.39-7.30(\mathrm{~m}, 2 \mathrm{H}, \mathrm{ArH}$, benzofuran + $\mathrm{C}_{6} \mathrm{H}_{2}$ ), 3.87 (s, $\left.3 \mathrm{H}, \mathrm{CH}_{3}\right), 3.80$ (s, $\left.3 \mathrm{H}, \mathrm{CH}_{3}\right), 3.73$ (s, $\left.3 \mathrm{H}, \mathrm{CH}_{3}\right)$. Anal. Calcd. for $\mathrm{C}_{19} \mathrm{H}_{17} \mathrm{NO}_{6}$ : C, 64.22; H, 4.82; N, 3.94. Found: C, 64.43; H, 4.90; N, 3.98.

5-Chloro-N-(4-methylphenyl)-1-benzofuran-2-carboxamide (12e). Yield 88\%, mp 156-157 ${ }^{\circ} \mathrm{C} .{ }^{1} \mathrm{H}$ NMR (400 MHz, DMSO): $\delta=10.46$ (s, $\left.1 \mathrm{H}, \mathrm{NH}\right), 7.88$ (d, J = 7.9 Hz, 1H, 
benzofuran), 7.73-7.63 (m, 4H, benzofuran $\left.+\mathrm{C}_{6} \mathrm{H}_{4}\right), 7.47(\mathrm{dd}, 8.8,2.2 \mathrm{~Hz}, 1 \mathrm{H}$, benzofuran), $7.13\left(\mathrm{~d}, J=8.3 \mathrm{~Hz}, 2 \mathrm{H}, \mathrm{C}_{6} \mathrm{H}_{4}\right), 2.25\left(\mathrm{~s}, 3 \mathrm{H}, \mathrm{CH}_{3}\right)$. Anal. Calcd. for $\mathrm{C}_{16} \mathrm{H}_{12} \mathrm{ClNO}_{2}: \mathrm{C}, 67.26 ; \mathrm{H}$, 4.23; N, 4.90. Found: C, 67.44; H, 4.16; N, 4.85.

Methyl 2-[(1-benzofuran-2-ylcarbonyl)amino]-4,5-dimethylthiophene-3-carboxylate (13). Yield 85\%, mp 147-148 ${ }^{\circ} \mathrm{C} .{ }^{1} \mathrm{H}$ NMR (400 MHz, DMSO): $\delta=12.08$ (s, 1H, NH), 7.81 (d, $J=7.8 \mathrm{~Hz}, 1 \mathrm{H}$, benzofuran), $7.74(\mathrm{~d}, J=9.0 \mathrm{~Hz}, 2 \mathrm{H}$, benzofuran), $7.53(\mathrm{t}, J=7.9 \mathrm{~Hz}, J=8.0$ $\mathrm{Hz}, 1 \mathrm{H}$, benzofuran), 7.38 (t, $J=7.4 \mathrm{~Hz}, 1 \mathrm{H}$, benzofuran), $3.90\left(\mathrm{~s}, 3 \mathrm{H}, \mathrm{O}-\mathrm{CH}_{3}\right), 2.22(\mathrm{~s}, 3 \mathrm{H}$, $\mathrm{CH}_{3}$ ), 2.17 (s, 3H, $\mathrm{CH}_{3}$ ). Anal. Calcd. for $\mathrm{C}_{17} \mathrm{H}_{15} \mathrm{NO}_{4} \mathrm{~S}$ : C, 61.99; H, 4.59; N, 4.25. Found: $\mathrm{C}$, $61.87 ; \mathrm{H}, 4.66 ; \mathrm{N}, 4.12$.

N-(2-oxo-2H-chromen-6-yl)-1-benzofuran-2-carboxamide (14). Yield 85\%, mp 242$243^{\circ} \mathrm{C} .{ }^{1} \mathrm{H}$ NMR (400 MHz, DMSO): $\delta=10.73$ (s, 1H, NH), 8.20 (s, 1H, chromen), 8.07 (d, $J$ $=8.3 \mathrm{~Hz}, 1 \mathrm{H}$, chromen $), 7.89(\mathrm{~d}, J=6.9 \mathrm{~Hz}, 1 \mathrm{H}$, benzofuran $), 7.80-7.68(\mathrm{~m}, 3 \mathrm{H}$, benzofuran+chromen), 7.48-7.34 (m, 3H, benzofuran+chromen), $6.47(\mathrm{~d}, J=8.5 \mathrm{~Hz}, 1 \mathrm{H}$, chromen). Anal. Calcd. for $\mathrm{C}_{18} \mathrm{H}_{11} \mathrm{NO}_{4}$ : C, 70.82; H, 3.63; N, 4.59. Found: C, 70.70; H, 3.74; $\mathrm{N}, 4.66$.

5-Chloro-N-1,3-thiazol-2-yl-1-benzofuran-2-carboxamide (15). Yield 78\%, mp 143 $144^{\circ} \mathrm{C} .{ }^{1} \mathrm{H}$ NMR (400 MHz, DMSO): $\delta 12.99$ (s, 1H, NH), $8.01-7.87$ (m, 2H, benzofuran), $7.80-7.69(\mathrm{~m}, 1 \mathrm{H}$, benzofuran), $7.61-7.43(\mathrm{~m}, 2 \mathrm{H}$, benzofuran+thiazole), $7.27(\mathrm{~s}, 1 \mathrm{H}$, thiazole). Anal. Calcd. for $\mathrm{C}_{12} \mathrm{H}_{7} \mathrm{ClN}_{2} \mathrm{O}_{2} \mathrm{~S}$ : C, 51.71; H, 2.53; N, 10.05. Found: C, 51.60; H, $2.48 ; \mathrm{N}, 10.11$.

N-1,3-Benzothiazol-2-yl-1-benzofuran-2-carboxamide (16). Yield 81\%, mp 256$257^{\circ} \mathrm{C} .{ }^{1} \mathrm{H}$ NMR (400 MHz, DMSO): $\delta=13.32$ (s, 1H, NH), 8.30 (s, 1H, benzothiazol), 8.14 (s, 1H, benzothiazol), $7.87(\mathrm{~d}, J=7.9 \mathrm{~Hz}, 1 \mathrm{H}$, benzofuran), $7.77-7.69(\mathrm{~m}, 3 \mathrm{H}$, benzofuran+benzothiazol), $7.61(\mathrm{dd}, J=8.6,1.9 \mathrm{~Hz}, 1 \mathrm{H}$, benzothiazol), $7.54(\mathrm{t}, J=8.2 \mathrm{~Hz}, J$ $=7.4 \mathrm{~Hz}, 1 \mathrm{H}$, benzofuran), 7.39 (t, $J=7.6 \mathrm{~Hz}, 1 \mathrm{H}$, benzofuran). Anal. Calcd. for $\mathrm{C}_{16} \mathrm{H}_{10} \mathrm{~N}_{2} \mathrm{O}_{2} \mathrm{~S}$ : C, 65.29; H, 3.42; N, 9.52. Found: C, 65.34; H, 3.55; N, 9.44.

N-[5-(3-methylbenzyl)-1,3-thiazol-2-yl]-1-benzofuran-2-carboxamide (17a). Yield 84\%, mp 163-164 ${ }^{\circ} \mathrm{C} .{ }^{1} \mathrm{H}$ NMR (400 MHz, DMSO): $\delta=12.80$ (s, 1H, NH), $7.96(\mathrm{~s}, 1 \mathrm{H}$, benzofuran), 7.80 (d, $J=7.7 \mathrm{~Hz}, 1 \mathrm{H}$, benzofuran), 7.69 (d, $J=8.3 \mathrm{~Hz}, 1 \mathrm{H}$, benzofuran), 7.48 (t, $J=8.1 \mathrm{~Hz}, 1 \mathrm{H}$, benzofuran), $7.33\left(\mathrm{~s}, 2 \mathrm{H}\right.$, thiazole $\left.+\mathrm{C}_{6} \mathrm{H}_{4}\right), 7.19(\mathrm{t}, J=7.5 \mathrm{~Hz}, 1 \mathrm{H}$, benzofuran), 7.08-7.02 (m, 3H, $\left.\mathrm{C}_{6} \mathrm{H}_{4}\right), 4.05\left(\mathrm{~s}, 2 \mathrm{H}, \mathrm{CH}_{2}\right), 2.26\left(\mathrm{~s}, 3 \mathrm{H}, \mathrm{CH}_{3}\right)$. Anal. Calcd. for $\mathrm{C}_{20} \mathrm{H}_{16} \mathrm{~N}_{2} \mathrm{O}_{2} \mathrm{~S}$ : C, 68.95; H, 4.63; N, 8.04. Found: C, 69.08; H, 4.77; N, 8.08.

$\mathrm{N}$-[5-(2-chlorobenzyl)-1,3-thiazol-2-yl]-1-benzofuran-2-carboxamide (17b). Yield $84 \%, \mathrm{mp} 188-189^{\circ} \mathrm{C} .{ }^{1} \mathrm{H}$ NMR (400 MHz, DMSO): $\delta=12.85$ (s, $\left.1 \mathrm{H}, \mathrm{NH}\right), 7.99$ (s, $\left.1 \mathrm{H}, \mathrm{C}_{6} \mathrm{H}_{4}\right)$, $7.82(\mathrm{~d}, \mathrm{~J}=7.8 \mathrm{~Hz}, 1 \mathrm{H}$, benzofuran), $7.71(\mathrm{~d}, J=8.5 \mathrm{~Hz}, 1 \mathrm{H}$, benzofuran), 7.52-7.45 (m, 3H, benzofuran $\left.+\mathrm{C}_{6} \mathrm{H}_{4}\right), 7.37-7.28\left(\mathrm{~m}, 4 \mathrm{H}\right.$, benzofuran+thiazole $\left.+\mathrm{C}_{6} \mathrm{H}_{4}\right), 4.23\left(\mathrm{~s}, 2 \mathrm{H}, \mathrm{CH}_{2}\right)$. Anal. Calcd. for $\mathrm{C}_{19} \mathrm{H}_{13} \mathrm{ClN}_{2} \mathrm{O}_{2} \mathrm{~S}$ : C, 61.87; H, 3.55; N, 7.59. Found: C, 62.02; H, 3.49; N, 7.64.

$\mathrm{N}$-[5-(2,3-dichlorobenzyl)-1,3-thiazol-2-yl]-1-benzofuran-2-carboxamide (17c). Yield 88\%, mp 173-174 ${ }^{\circ} \mathrm{C} .{ }^{1} \mathrm{H}$ NMR (400 MHz, DMSO): $\delta=12.84$ (s, 1H, NH), $7.96(\mathrm{~s}, 1 \mathrm{H}$, $\left.\mathrm{C}_{6} \mathrm{H}_{4}\right), 7.80(\mathrm{~d}, J=7.5 \mathrm{~Hz}, 1 \mathrm{H}$, benzofuran), $7.69(\mathrm{~d}, \mathrm{~J}=8.2 \mathrm{~Hz}, 1 \mathrm{H}$, benzofuran), $7.53(\mathrm{~d}, J=$ $7.9 \mathrm{~Hz}, 1 \mathrm{H}$, benzofuran), $7.48\left(\mathrm{t}, J=7.9 \mathrm{~Hz}, 1 \mathrm{H}\right.$, benzofuran), $7.42\left(\mathrm{~d}, J=7.6 \mathrm{~Hz}, 1 \mathrm{H}, \mathrm{C}_{6} \mathrm{H}_{4}\right)$, 7.36-7.31 (m, 3H, benzofuran+thiazole $\left.+\mathrm{C}_{6} \mathrm{H}_{4}\right), 4.27\left(\mathrm{~s}, 2 \mathrm{H}, \mathrm{CH}_{2}\right)$. Anal. Calcd. for $\mathrm{C}_{19} \mathrm{H}_{12} \mathrm{Cl}_{2} \mathrm{~N}_{2} \mathrm{O}_{2} \mathrm{~S}$ : C, 56.59; H, 3.00; N, 6.95. Found: C, 56.52; H, 3.06; N, 6.89.

$N$-\{5-[4-chloro-3-(trifluoromethyl)benzyl]-1,3-thiazol-2-yl\}-1-benzofuran-2-

carboxamide (17d). Yield 79\%, mp 205-206 ${ }^{\circ} \mathrm{C} .{ }^{1} \mathrm{H}$ NMR (400 MHz, DMSO): $\delta=12.83$ (s, $1 \mathrm{H}, \mathrm{NH}), 7.96\left(\mathrm{~s}, 1 \mathrm{H}, \mathrm{C}_{6} \mathrm{H}_{4}\right), 7.82-7.78(\mathrm{~m}, 2 \mathrm{H}$, benzofuran $), 7.70-7.66(\mathrm{~m}, 2 \mathrm{H}$, benzofuran+ 
$\left.\mathrm{C}_{6} \mathrm{H}_{4}\right), 7.60\left(\mathrm{~d}, J=8.1 \mathrm{~Hz}, 1 \mathrm{H}, \mathrm{C}_{6} \mathrm{H}_{4}\right), 7.48$ (t, $J=8.0 \mathrm{~Hz}, 1 \mathrm{H}$, benzofuran), 7.38-7.32 (m, 2H, benzofuran+thiazole), $4.22\left(\mathrm{~s}, 2 \mathrm{H}, \mathrm{CH}_{2}\right)$. Anal. Calcd. for $\mathrm{C}_{20} \mathrm{H}_{12} \mathrm{ClF}_{3} \mathrm{~N}_{2} \mathrm{O}_{2} \mathrm{~S}: \mathrm{C}, 54.99 ; \mathrm{H}, 2.77$; N, 6.41. Found: C, 54.85; H, 2.82; N, 6.55 .

Synthesis of N-[3-(2-oxopropyl)-1,2,4-thiadiazol-5-yl]-1-benzofuran-2-carboxamide (21). 0,005 mol Benzofuran-2-carbonyl chloride (1a), was dissolved in $10 \mathrm{ml}$ of anhydrous acetonitrile and 0,005 mol of potassium thiocyanate was added under stirring then the resulting mixture at $60^{\circ} \mathrm{C}$ was heated for $30 \mathrm{~min}$. Next $0,0034 \mathrm{~mol}$ of 5-methyl-1,2-oxazol-3-amine was added, and the mixture was heated under stirring for $2 \mathrm{~h}$ and poured into water. The precipitate was filtered off, washed with several portions of water, and purified by recrystallization from ethanol. Yield 64\%, mp 108-109 ${ }^{\circ} \mathrm{C} .{ }^{1} \mathrm{H}$ NMR (400 MHz, DMSO): $\delta=13.79$ (s, 1H, NH), 7.91 (s, $1 \mathrm{H}$, benzofuran), 7.83 (d, $J=7.6 \mathrm{~Hz}, 1 \mathrm{H}$, benzofuran), $7.71(\mathrm{~d}, J=8.2 \mathrm{~Hz}, 1 \mathrm{H}$, benzofuran), 7.51 (t, $J=7.8 \mathrm{~Hz}, 1 \mathrm{H}$, benzofuran), 7.35 (t, $J=7.3 \mathrm{~Hz}, 1 \mathrm{H}$, benzofuran), $4.02\left(\mathrm{~s}, 3 \mathrm{H}, \mathrm{CH}_{2}\right)$, 2.17 (s, 3H, $\left.\mathrm{CH}_{3}\right)$. Anal. Calcd. for $\mathrm{C}_{14} \mathrm{H}_{11} \mathrm{~N}_{3} \mathrm{O}_{3} \mathrm{~S}: \mathrm{C}, 55.81 ; \mathrm{H}, 3.68 ; \mathrm{N}, 13.95$. Found: $\mathrm{C}, 55.66$; H, 3.79; N, 13.88 .

\subsection{Pharmacology.}

The tested compounds were added to the culture at a single concentration $\left(10^{-5} \mathrm{M}\right)$, and the cultures were incubated for $48 \mathrm{~h}$. Endpoint determinations were made with a proteinbinding dye, sulforhodamine B (SRB). Results for each tested compound were reported as the percent growth of the treated cells when compared to the untreated control cells.

The percent growth was evaluated spectrophotometrically versus not treated controls. The cytotoxic and/or growth inhibitory effects of the most active compounds were tested in vitro against the full panel of about 60 human tumor cell lines at 10-fold dilutions of five concentrations ranging from $10^{-4}$ to $10^{-8} \mathrm{M}$. The 48 -h continuous drug exposure protocol was followed, and an SRB protein assay was used to estimate cell viability or growth.

Using the seven absorbance measurements [time zero, (Tz), control growth in the absence of drug, (C), and test growth in the presence of drug at the five concentration levels (Ti)], the percent growth was calculated at each of the drug concentrations levels. Percent growth inhibition was calculated as:

$[(\mathrm{Ti}-\mathrm{Tz}) /(\mathrm{C}-\mathrm{Tz})] \times 100$ for concentrations for which $\mathrm{Ti} \geq \mathrm{Tz}$;

$[(\mathrm{Ti}-\mathrm{Tz}) / \mathrm{Tz}] \times 100$ for concentrations for which $\mathrm{Ti}<\mathrm{Tz}$.

Three dose-response parameters were calculated for each compound. Growth inhibition of $50 \%\left(\mathrm{GI}_{50}\right)$ was calculated from $[(\mathrm{Ti}-\mathrm{Tz}) /(\mathrm{C}-\mathrm{Tz})] \times 100-50$, which is the drug concentration resulting in a $50 \%$ lower net protein increase in the treated cells (measured by SRB staining) as compared to the net protein increase seen in the control cells.

The drug concentration resulting in total growth inhibition (TGI) was calculated from $\mathrm{Ti}=\mathrm{Tz}$. The $\mathrm{LC}_{50}$ (concentration of drug resulting in a 50\% reduction in the measured protein at the end of the drug treatment as compared to that at the beginning) indicating a net loss of cells following treatment was calculated from $[(\mathrm{Ti}-\mathrm{Tz}) / \mathrm{Tz}] \times 100=-50$.

Values were calculated for each of these three parameters if the level of activity was reached; however, if the effect was not reached or was exceeded, the value for that parameter was expressed as more or less than the maximum or minimum concentration was tested. 


\section{Results and Discussion}

\subsection{Synthesis of some benzofurancarboxamides.}

We were continuing the systematic study of benzofurane derivatives as potential drug candidates we spent synthesis and anticancer activity screening of among the specified class of compounds. The target benzofurancarboxamides were synthesized from chloroanhydrides of commercially available benzofuran-2-carboxylic acids (1a, b) and arylamines (2a-e), Gewald amine (3), 6-aminocoumarine (4), 2-aminothiazole (5), 2-aminobenzothiazole (6), and 2amino-5-arylmethylthiazoles (7a-d). 2-Amino-5-arylmethylthiazoles (7a-d) were prepared from diazonium salts (8a-d) and acrolein (9) according to procedures described earlier [56]. At first stage (8a-d) and acrolein (9) in condition of Meerwein reaction [57] to form 3-aryl-2chloropropanals (10a-d) which, by the reaction with thiourea (11), were transformed into target 2-amino-5-arylmethylthiazoles (7a-d). The acylation reaction was performed in dry dioxane at room temperature in the presence triethylamine (Scheme 1).

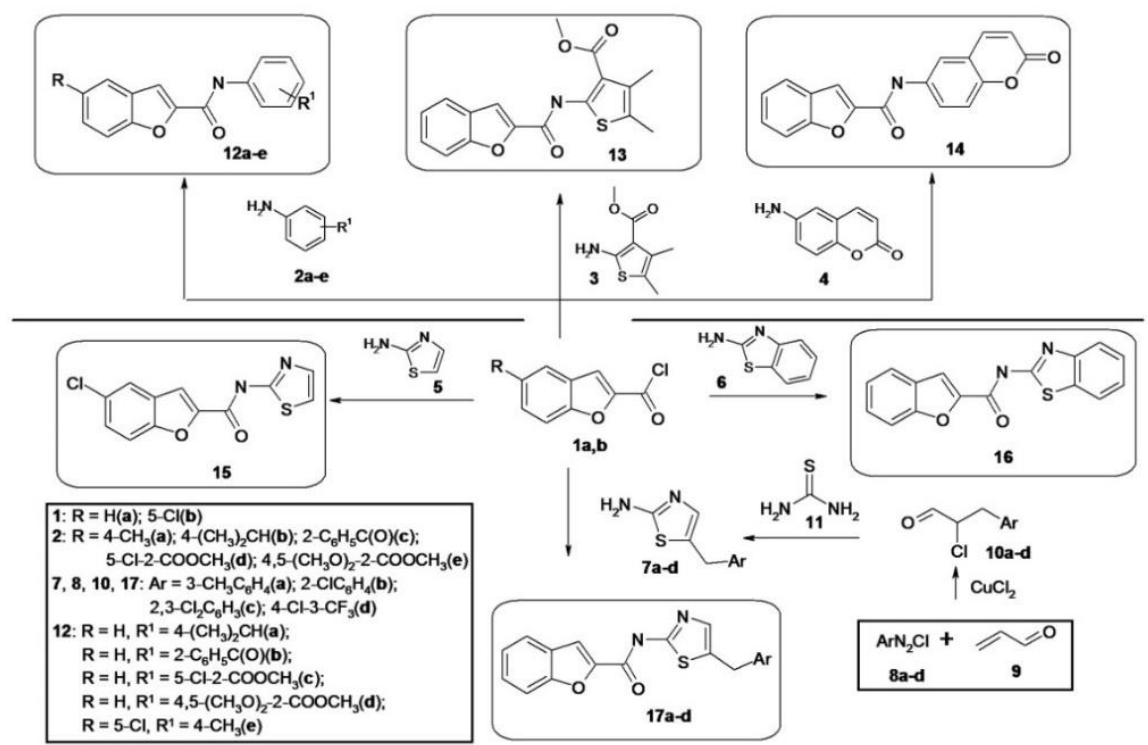

Scheme 1. Synthesis of benzofurancarboxamides (12-17).

The amide $\mathbf{2 1}$ was prepared according to scheme 2. Acyl isothiocyanates $\mathbf{1 9}$ generated in situ from acid chlorides $\mathbf{1 a}$ and potassium thiocyanate reacted with 5-methyl-1,2-oxazol-3amine 18. The expected products of this reaction, $\mathrm{N}$-acylthioureas were not isolated, for they underwent recyclization involving the opening of the 1,2-oxazole ring and closure of 1,2,4thiadiazole ring [58] to produce finally $\mathrm{N}$-[3-(2-oxopropyl)-1,2,4-thiadiazol-5-yl]-1benzofuran-2-carboxamide.

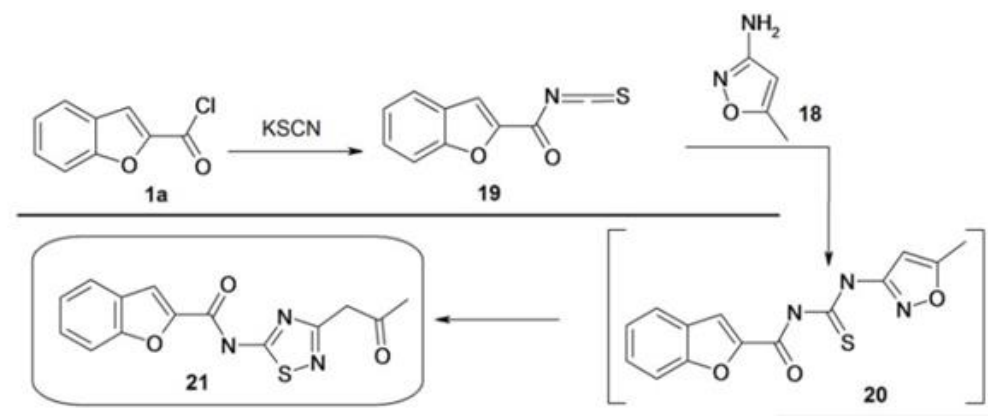

Scheme 2. Synthesis of $N$-[3-(2-oxopropyl)-1,2,4-thiadiazol-5-yl]-1-benzofuran-2-carboxamide (21). 
The structures of the synthesized compounds and their composition were confirmed by quantitative elemental analysis and ${ }^{1} \mathrm{H}$ NMR spectroscopy. The spectroscopic data of all new compounds correspond to the proposed structures.

\subsection{Pharmacology.}

The synthesized compounds were selected by the National Cancer Institute (NCI) Developmental Therapeutics Program (www.dtp.nci.nih.gov) for the in vitro cell line screening to investigate their anticancer activity. The primary anticancer assay was performed at approximately sixty human tumor cell lines panel derived from nine neoplastic diseases, the protocol of the Drug Evaluation Branch, National Cancer Institute, Bethesda [59-63].

Results for each tested compound were reported as the percentage of growth of the treated cells when compared to the untreated control cells. The percentage of growth was evaluated spectrophotometrically versus controls not treated with test agents. The screening results are shown in Table 1.

Table 1. Cytotoxic activity of the tested compounds in the concentration $10^{-5} \mathrm{M}$ against 60 cancer cell lines.

\begin{tabular}{|c|c|c|c|}
\hline $\begin{array}{c}\text { Test } \\
\text { compounds }\end{array}$ & Average growth, $\%$ & Range of growth, \% & $\begin{array}{l}\text { Most sensitive cell } \\
\text { line (cancer line/type) GP, \% }\end{array}$ \\
\hline $12 \mathbf{a}$ & 85.61 & $56.95-110.16$ & $\begin{array}{l}\text { CAKI-1 (Renal Cancer) 56.95 } \\
\text { HOP-92 (Non-Small Cell Lung Cancer) } 57.53 \\
\text { SF-295 (CNS Cancer) 63.71 }\end{array}$ \\
\hline $12 b$ & 77.40 & $17.09-108.35$ & $\begin{array}{l}\text { SNB-75 CNS Cancer 17.09 } \\
\text { OVCAR-4 Ovarian Cancer } 27.58 \\
\text { HS 578T Breast Cancer 28.88 }\end{array}$ \\
\hline $12 \mathrm{c}$ & 89.84 & $56.02-110.81$ & $\begin{array}{l}\text { CAKI-1 Renal Cancer } 56.02 \\
\text { UO-31 Renal Cancer 56.16 } \\
\text { HOP-92 Non-Small Cell Lung Cancer } 60.93\end{array}$ \\
\hline 12d & 83.30 & $51.53-104.89$ & $\begin{array}{l}\text { HOP-92 Non-Small Cell Lung Cancer } 51.53 \\
\text { MCF7 Breast Cancer 59.06 } \\
\text { OVCAR-8 Ovarian Cancer } 61.95\end{array}$ \\
\hline $12 \mathrm{e}$ & 100.39 & $80.85-122.53$ & HOP-92 (Non-Small Cell Lung Cancer) 80.85 \\
\hline 13 & 60.31 & $17.47-112.78$ & $\begin{array}{l}\text { UO-31 Renal Cancer } 63.22 \\
\text { HOP-92 Non-Small Cell Lung Cancer } 68.80\end{array}$ \\
\hline 14 & 91.38 & $65.20-126.53$ & $\begin{array}{l}\text { NCI-H522 Non-Small Cell Lung Cancer } 65.20 \\
\text { UO-31 Renal Cancer } 74.91\end{array}$ \\
\hline 15 & 97.73 & $69.54-133.30$ & HCT-116 Colon Cancer 69.54 \\
\hline 16 & 102.14 & $79.49-120.17$ & $\begin{array}{l}\text { HOP-92 Non-Small Cell Lung Cancer } 79.49 \\
\text { CCRF-CEM Leukemia } 80.88\end{array}$ \\
\hline $17 \mathbf{a}$ & 28.76 & $-54.45-71.84$ & $\begin{array}{l}\text { MDA-MB-435 Melanoma -54.45 } \\
\text { NCI-H522 Non-Small Cell Lung Cancer - } \\
32.39 \\
\text { RXF } 393 \text { Renal Cancer -8.33 } \\
\text { OVCAR-3 Ovarian Cancer -5.09 } \\
\text { SF-295 CNS Cancer } 4.95 \\
\text { SF-539 CNS Cancer } 4.21 \\
\end{array}$ \\
\hline $17 \mathrm{~b}$ & 81.21 & $14.65-105.61$ & $\begin{array}{l}\text { SR Leukemia } 14.65 \\
\text { MDA-MB-435 Melanoma } 31.21 \\
\text { T-47D Breast Cancer } 33.04 \\
\text { MCF7 Breast Cancer } 33.60 \\
\end{array}$ \\
\hline 17c & -4.31 & $-74.59-44.93$ & $\begin{array}{l}\text { TK-10 Renal Cancer - } 74.59 \\
\text { OVCAR-3 Ovarian Cancer -60.14 } \\
\text { ACHN Renal Cancer -60.23 } \\
\text { HCT-116 Colon Cancer -60.26 } \\
\text { 786-0 Renal Cancer -56.06 } \\
\text { HT29 Colon Cancer -54.29 }\end{array}$ \\
\hline 17d & 44.38 & $-42.84-79.81$ & $\begin{array}{l}\text { SK-MEL-5 Melanoma -42.84 } \\
\text { UACC-62 Melanoma 7.33 } \\
\text { KM12 Colon Cancer 9.26 } \\
\text { HCC-2998 Colon Cancer } 11.92\end{array}$ \\
\hline
\end{tabular}

The screening results are shown in Table 1. The synthesized compounds display a different level of activity in the in vitro screening on the tested cell lines. Compounds 12a, 13, 
17b showed moderate activity with GP $=79.40-89.84 \%$ while 17a, $\mathbf{c}, \mathbf{d}$ high - with GP = $4.31-44.38 \%$. To the most active compound, 17c was susceptible to cell line TK-10 ACHN and 786-0 (Renal Cancer), OVCAR-3 (Ovarian Cancer), HCT-116, and HT29 (Colon Cancer). In all mentioned cases, a high cytotoxic effect was observed.

Finally, compound 17a, c, $\mathbf{d}$ was selected for an advanced assay against a panel of approximately sixty tumor cell lines at 10 -fold dilutions of five concentrations $(100 \mu \mathrm{M}, 10$ $\mu \mathrm{M}, 1.0 \mu \mathrm{M}, 0.1 \mu \mathrm{M}$, and $0.01 \mu \mathrm{M}$ ) (Table 2).

The percentage of growth was evaluated spectrophotometrically versus controls not treated with test agents after 48-h exposure and using SRB protein assay to estimate cell viability or growth. Dose-response parameters were calculated for each cell line:

GI50 - molar concentration of the compound that inhibits 50\% net cell growth;

TGI - molar concentration of the compound leading to the total inhibition;

LC50- molar concentration of the compound leading to 50\% net cell death.

Furthermore, mean graph midpoints (MG_MID) were calculated for GI50 and TGI, giving an average activity parameter over all cell lines for the tested compound. For the MG_MID calculation, insensitive cell lines were included with the highest concentration tested. Compounds 17a showed high inhibition activity $\left(\mathrm{GI}_{50}<10 \mu \mathrm{M}\right)$ against all 58 human tumor cell lines with MG-MID GI50 values of $2.03 \mu \mathrm{M}$ 17c - against 56 of 58 (MG-MID = 3.26 $\mu \mathrm{M})$ and $\mathbf{1 7 d}$ against 53 of $58(\mathrm{MG}-\mathrm{MID}=3.26 \mu \mathrm{M})$ human tumor cell lines. The colon cancer subpanel demonstrated the highest sensitivity to compound 17a and 17c with a mean GI50 value of $0.87 \mu \mathrm{M}$ and $0.84 \mu \mathrm{M}$, respectively. The most sensitive line was T-47D (Breast Cancer, $\left.\mathrm{GI}_{50}=0.088 \mu \mathrm{M}\right)$.

Table 2. Influence of compound $\mathbf{1 7 a}, \mathbf{c}, \mathbf{d}$ on the growth of tumor cell lines.

\begin{tabular}{|c|c|c|c|c|c|c|}
\hline \multirow[t]{3}{*}{ Panel/Cell Line } & \multicolumn{6}{|c|}{ Growth inhibitory concentration $\mu \mathrm{M}$} \\
\hline & \multicolumn{2}{|c|}{$17 \mathbf{a}$} & \multicolumn{2}{|c|}{$17 \mathrm{c}$} & \multicolumn{2}{|c|}{ 17d } \\
\hline & $\mathrm{GI}_{50}$ & TGI & $\mathrm{GI}_{50}$ & TGI & $\mathrm{GI}_{50}$ & TGI \\
\hline \multicolumn{7}{|c|}{ Leucemia } \\
\hline CCRF-CEM & 1.32 & 11.4 & 11.9 & 37.5 & 2.42 & $>100$ \\
\hline HL-60 (TB) & 0.318 & 2.09 & 0.666 & $>100$ & $>100$ & $>100$ \\
\hline K-562 & 0.357 & 11.8 & 0.427 & $>100$ & 0.963 & $>100$ \\
\hline MOLT-4 & 2.42 & 25.2 & 63.0 & $>100$ & $>100$ & $>100$ \\
\hline RPMI-8226 & 1.34 & 6.61 & 8.54 & $>100$ & 28.6 & $>100$ \\
\hline SR & 0.309 & 2.68 & 0.368 & $>100$ & 15.4 & $>100$ \\
\hline \multicolumn{7}{|c|}{ Non-Small Cell Lung Cancer } \\
\hline A549/ATCC & 0.541 & 28.9 & 1.27 & 9.38 & 0.738 & $>100$ \\
\hline EKVX & - & - & 3.12 & $>100$ & 4.20 & $>100$ \\
\hline HOP-62 & 1.16 & 16.7 & 1.30 & 4.16 & 6.13 & 27.5 \\
\hline HOP-92 & 0.268 & 3.98 & - & - & 1.77 & 5.57 \\
\hline NCI-H226 & 7.76 & 55.0 & 3.15 & 56.9 & 6.93 & 74.3 \\
\hline NCI-H23 & 4.35 & $>100$ & 2.43 & 25.5 & 9.29 & $>100$ \\
\hline NCI-H322M & 2.99 & 94.7 & 1.74 & 34.5 & 9.86 & $>100$ \\
\hline NCI-H460 & 0.388 & 11.0 & 1.33 & 5.11 & 0.570 & 70.1 \\
\hline NCI-H522 & 0.401 & 8.15 & 0.420 & 7.01 & 5.13 & 38.4 \\
\hline \multicolumn{7}{|c|}{ CNS Cancer } \\
\hline SF-268 & 3.12 & 21.6 & 2.73 & 34.9 & 2.95 & 34.5 \\
\hline SF-295 & 9.53 & 32.9 & 0.756 & 3.54 & 0.527 & 11.7 \\
\hline SF-539 & 1.68 & 9.33 & 2.07 & 6.90 & - & - \\
\hline SNB-19 & 5.60 & 42.4 & 2.17 & 25.0 & 4.54 & 27.3 \\
\hline SNB-75 & 2.11 & 13.9 & 1.60 & 3.57 & 2.07 & 5.02 \\
\hline U251 & 0.739 & 14.9 & 1.08 & 3.53 & 3.29 & 18.5 \\
\hline \multicolumn{7}{|c|}{ Colon cancer } \\
\hline COLO 205 & 0.573 & 4.04 & 2.28 & $>100$ & 8.87 & $>100$ \\
\hline HCC-2998 & 4.05 & $>100$ & 0.925 & 9.43 & 0.142 & $>100$ \\
\hline HCT-116 & 0.530 & 62.4 & 1.13 & 3.23 & 2.47 & $>100$ \\
\hline HCT-15 & 0.0522 & $>100$ & 0.0547 & $>100$ & 0.0667 & $>100$ \\
\hline HT29 & 0.394 & 13.0 & 0.501 & 4.07 & 11.9 & $>100$ \\
\hline
\end{tabular}




\begin{tabular}{|c|c|c|c|c|c|c|}
\hline \multirow[t]{3}{*}{ Panel/Cell Line } & \multicolumn{6}{|c|}{ Growth inhibitory concentration $\mu \mathrm{M}$} \\
\hline & \multicolumn{2}{|c|}{ 17a } & \multicolumn{2}{|c|}{$17 \mathrm{c}$} & \multicolumn{2}{|c|}{ 17d } \\
\hline & $\mathrm{GI}_{50}$ & TGI & $\mathrm{GI}_{50}$ & TGI & $\mathrm{GI}_{50}$ & TGI \\
\hline KM12 & 0.0749 & 11.0 & 0.0855 & 3.47 & 0.0364 & $>100$ \\
\hline SW-620 & 0.440 & 24.6 & 0.920 & $>100$ & 6.54 & $>100$ \\
\hline \multicolumn{7}{|c|}{ Melanoma } \\
\hline LOX IMVI & 1.11 & 20.6 & 1.99 & $>100$ & 2.12 & $>100$ \\
\hline MALME-3M & 1.99 & 18.3 & 1.42 & 25.5 & 3.81 & $>100$ \\
\hline M14 & 0.667 & $>100$ & 0.858 & $>100$ & 1.04 & $>100$ \\
\hline MDA-MB-435 & 0.208 & 0.525 & 0.245 & 0.771 & 0.527 & $>100$ \\
\hline SK-MEL-2 & 0.704 & 12.1 & 0.138 & 3.02 & 3.16 & 33.1 \\
\hline SK-MEL-28 & 4.07 & $>100$ & 2.69 & $>100$ & 16.5 & $>100$ \\
\hline SK-MEL-5 & 0.190 & 1.61 & 0.339 & 3.47 & 2.64 & 8.36 \\
\hline UACC-257 & 1.15 & 24.3 & 5.79 & $>100$ & 9.77 & $>100$ \\
\hline UACC-62 & 0.565 & 14.9 & 0.139 & 4.60 & - & - \\
\hline \multicolumn{7}{|c|}{ Ovarian Cancer } \\
\hline IGROV1 & 2.75 & 35.8 & 1.96 & 21.2 & 7.54 & $>100$ \\
\hline OVCAR-3 & 0.715 & 3.18 & 1.30 & 3.04 & 2.72 & 10.1 \\
\hline OVCAR-4 & 2.03 & 13.9 & 0.0396 & $>100$ & 8.39 & $>100$ \\
\hline OVCAR-5 & 6.95 & 52.9 & - & - & - & - \\
\hline OVCAR-8 & 2.69 & 17.0 & 2.61 & $>100$ & 3.49 & 55.1 \\
\hline NCI/ADR-RES & 0.760 & 27.7 & 0.673 & $>100$ & 8.48 & $>100$ \\
\hline SK-OV-3 & 2.88 & 21.9 & 1.63 & 4.17 & 5.16 & 22.2 \\
\hline \multicolumn{7}{|c|}{ Prostate Cancer } \\
\hline PC-3 & 1.53 & 15.4 & 2.45 & 18.4 & 2.88 & 51.8 \\
\hline DU-145 & 4.03 & 59.9 & 4.67 & $>100$ & 8.45 & $>100$ \\
\hline \multicolumn{7}{|c|}{ Renal Cancer } \\
\hline 786-0 & 2.72 & 15.0 & 1.66 & 3.65 & 2.56 & 11.2 \\
\hline A498 & 2.19 & 8.72 & 1.40 & 4.71 & 2.59 & 9.07 \\
\hline ACHN & 2.44 & 22.6 & - & - & 1.01 & 14.0 \\
\hline CAKI-1 & 1.24 & 17.5 & 1.38 & 20.4 & 0.372 & 50.9 \\
\hline RXF 393 & 3.32 & 18.9 & 1.96 & 8.90 & 5.47 & 25.4 \\
\hline SN12C & 2.57 & $>100$ & 3.64 & $>100$ & 22.2 & $>100$ \\
\hline TK-10 & 1.39 & 11.2 & 1.63 & 4.59 & 3.72 & 19.3 \\
\hline UO-31 & 2.78 & 14.2 & 2.44 & 9.54 & 0.534 & 65.0 \\
\hline \multicolumn{7}{|c|}{ Breast Cancer } \\
\hline MCF7 & 0.0767 & 29.2 & 0.0651 & $>100$ & 1.69 & $>100$ \\
\hline $\begin{array}{l}\text { MDA-MB- } \\
\text { 231/ATCC }\end{array}$ & 1.55 & 22.0 & 0.573 & 5.73 & 2.80 & $>100$ \\
\hline HS 578T & 1.76 & 13.9 & 2.00 & 8.29 & 3.79 & 33.3 \\
\hline BT-549 & 4.00 & 74.3 & 10.6 & 66.7 & 18.4 & $>100$ \\
\hline T-47D & 0.0282 & 13.1 & 0.0255 & 21.0 & - & - \\
\hline MDA-MB-468 & 0.769 & 11.0 & 0.591 & 6.34 & 3.36 & 20.7 \\
\hline
\end{tabular}

The selectivity index (SI) obtained by dividing the full panel MG-MID $(\mu \mathrm{M})$ of the compound 17a by its sub-panel MG-MID $(\mu \mathrm{M})$ was considered as a measure of compound's selectivity. Ratios between 3 and 6 refer to moderate selectivity, ratios greater than 6 indicate high selectivity toward the corresponding cell line, while compounds not meeting either of the criteria are rated non-selective [59]. In this context, the active compounds $\mathbf{1 7} \mathbf{c}$ and $\mathbf{1 7 d}$ demonstrates the same moderate selectivity toward colon and CNS cancer cell lines (Table 3).

Table 3. Anticancer selectivity pattern of the most active compounds $\mathbf{1 7 a}, \mathbf{c}, \mathbf{d}$.

\begin{tabular}{|c|c|c|c|c|c|c|c|c|c|c|}
\hline \multirow[t]{2}{*}{ Cpd } & \multirow[t]{2}{*}{ Parameters } & \multicolumn{9}{|c|}{ Subpanel tumor cell lines } \\
\hline & & $\mathbf{L}$ & NSCLC & ColC & CNSC & M & OV & RC & PC & BC \\
\hline \multirow[t]{4}{*}{$17 \mathbf{a}$} & $\mathrm{GI}_{50}$ & 1.01 & 2.23 & 0.87 & 3.80 & 1.18 & 2.68 & 2.33 & 2.78 & 1.36 \\
\hline & SI* & 2.01 & 0.91 & 2.33 & 0.53 & 1.72 & 0.76 & 0.87 & 0.73 & 1.49 \\
\hline & TGI & 9.96 & 39.80 & 45.01 & 22.51 & 32.48 & 24.63 & 26.02 & 37.65 & 27.25 \\
\hline & SI** & 2.96 & 0.74 & 0.65 & 1.31 & 0.91 & 1.20 & 1.13 & 0.78 & 1.08 \\
\hline \multirow[t]{4}{*}{$17 \mathrm{c}$} & $\mathrm{GI}_{50}$ & 14.15 & 1.85 & 0.84 & 1.73 & 1.51 & 1.37 & 2.06 & 3.56 & 2.31 \\
\hline & SI* & 0.23 & 1.76 & 3.88 & 1.88 & 2.16 & 2.38 & 1.58 & 0.92 & 1.41 \\
\hline & TGI & 89.58 & 30.32 & 45.74 & 12.91 & 48.60 & 54.74 & 21.68 & 59.20 & 34.68 \\
\hline & SI** & 0.49 & 1.46 & 0.97 & 3.42 & 0.91 & 0.81 & 2.04 & 0.75 & 1.27 \\
\hline \multirow[t]{2}{*}{ 17d } & $\mathrm{GI}_{50}$ & 41.23 & 4.96 & 4.29 & 2.68 & 4.95 & 5.96 & 4.81 & 5.67 & 6.01 \\
\hline & SI* & 0.22 & 1.80 & 2.09 & 3.34 & 1.81 & 1.50 & 1.86 & 1.58 & 1.49 \\
\hline
\end{tabular}




\begin{tabular}{|c|c|c|c|c|c|c|c|c|c|c|}
\hline \multirow[t]{4}{*}{ Cpd } & \multirow[t]{2}{*}{ Parameters } & \multicolumn{9}{|c|}{ Subpanel tumor cell lines } \\
\hline & & $\mathbf{L}$ & NSCLC & ColC & CNSC & $\mathbf{M}$ & OV & $\mathbf{R C}$ & $\mathbf{P C}$ & BC \\
\hline & TGI & 100.00 & 68.43 & 100.00 & 19.40 & 80.18 & 64.57 & 36.86 & 75.90 & 70.80 \\
\hline & SI** & 0.68 & 1.00 & 0.68 & 3.52 & 0.85 & 1.06 & 1.86 & 0.90 & 0.97 \\
\hline
\end{tabular}

$\mathrm{L}$ - leukemia, NSCLCC - non-small cell lung cancer, ColC - colon cancer, CNSC - CNS cancer, M - melanoma, OVovarian cancer, $\mathrm{RC}$ - renal cancer, $\mathrm{PC}$ - prostate cancer, $\mathrm{BC}$ - breast cancer.

*Selectivity index at the $\mathrm{GI}_{50}$ level. **Selectivity index at the TGI level

In table 4 the results of the mean growth inhibitory concentration $(\mathrm{GI} 50, \mu \mathrm{M})$ of compound 17a, c, d in comparison with 5-FU, Cisplatin, and Curcumin.

Table 4. Mean growth inhibitory concentration (GI50, $\mu \mathrm{M})$ of compound $17 \mathrm{a}, \mathrm{c}, \mathrm{d}$ in comparison with 5-FU, Cisplatin, and Curcumin.

\begin{tabular}{c|c|c|c|c|c|c|c|c|c|c}
\multicolumn{10}{c|}{ Subpanel tumor cell lines } \\
\hline Cpd & L & NSCLC & ColC & CNSC & M & OV & RC & PC & BC & MG-MID \\
\hline 17a & 1.01 & 2.23 & 0.87 & 3.80 & 1.18 & 2.68 & 2.33 & 2.78 & 1.36 & 2.03 \\
\hline 17c & 14.15 & 1.85 & 0.84 & 1.73 & 1.51 & 1.37 & 2.06 & 3.56 & 2.31 & 3.26 \\
\hline 17d & 41.23 & 4.96 & 4.29 & 2.68 & 4.95 & 5.96 & 4.81 & 5.67 & 6.01 & 8.95 \\
\hline 5-FU & 15.1 & $>100$ & 8.4 & 72.1 & 70.6 & 61.4 & 45.6 & 22.7 & 76.4 & 52.5 \\
\hline Cisplatin & 6.3 & 9.4 & 21.0 & 4.7 & 8.5 & 6.3 & 10.2 & 5.6 & 13.3 & 9.48 \\
\hline Curcumin & 3.7 & 9.2 & 4.7 & 5.8 & 7.1 & 8.9 & 10.2 & 11.2 & 5.9 & 7.41
\end{tabular}

The tested compound $\mathbf{1 7 a} \mathbf{a}, \mathbf{c}, \mathbf{d}$ is effective against all of the cell lines, as the full panel mean-graph shows it. MG-MID $(\mu \mathrm{M})$ values for $\mathbf{1 7 a}, \mathbf{c}, \mathbf{d}$ are less than those for 5-Fluorouracil, Curcumin, and Cisplatin when tested in the same manner.

\section{Conclusions}

To develop novel anticancer agents, a series of novel benzofurancarboxamides were synthesized. The structures of the obtained compounds were confirmed by $1 \mathrm{H}$ NMR spectroscopy and elemental analysis. Anticancer activity screening was carried out within the framework of the Developmental Therapeutic Program of the National Cancer Institute's (DTP, NCI, Bethesda, Maryland, USA). The synthesized compounds were exhibited high activity against most of the cancer cells. The results prove the necessity of further investigations to clarify the features underlying the antitumor effect of tested compounds.

\section{Funding}

This research received no external funding.

\section{Acknowledgments}

We are grateful Drug Synthesis and Chemistry Branch, National Cancer Institute, Bethesda, MD, USA, for in vitro evaluation of the anticancer activity.

\section{Conflicts of Interest}

The authors declare no conflict of interest.

\section{References}

1. Khanam, H.; Shamsuzzaman. Bioactive Benzofuran derivatives: A review. European Journal of Medicinal Chemistry 2015, 97, 483-504, https://doi.org/10.1016/j.ejmech.2014.11.039.

2. Chand, K.; Rajeshwari; Hiremathad, A.; Singh, M.; Santos, M.; Keri, R.S. A review on antioxidant potential of bioactive heterocycle benzofuran: Natural and synthetic derivatives. Pharmacol Rep. 2017, 69, 281-295, https://doi.org/10.1016/j.pharep.2016.11.007. 
3. Bhargava, S.; Rathore, D. Synthetic Routes and Biological Activities of Benzofuran and its Derivatives: A Review. Letters in Organic Chemistry 2017, https://doi.org/10.2174/1570178614666170321125853.

4. Napiyrkowska, M.; Ciesrlak, M.; Kazrmierczak-Baranrska, J.; Krylewska-Golinrska, K.; Nawrot, B. Synthesis of New Derivatives of Benzofuran as Potential Anticancer Agents. Molecules 2019, 24, 15291545, https://doi.org/10.3390/molecules24081529.

5. Miao, Y.H.; Hu, Y.H.; Yang, J.; Liu, T.; Sun, J., Wang, X.J. Natural source, bioactivity and synthesis of benzofuran derivatives. RSC Advances 2019, 9, 27510-27540, https://doi.org/10.1039/C9RA04917G.

6. Alper-Hayta, S.; Arisoy, M.; Temiz-Arpaci, O.; Yildiz, I.; Aki, E.; Ozkan, S.; Kaynak, F. Synthesis, antimicrobial activity, pharmacophore analysis of some new (substitutedphenyl/benzyl)-5-[(2benzofuryl)carboxamido]benz oxazoles. European Journal of Medicinal Chemistry 2008, 43, 2568-2578, https://doi.org/10.1016/j.ejmech.2007.12.019.

7. Hranjeca, M.; Sovic, I.; Ratkaj, I.; Pavlovic, G.; Ilic, N.; Valjalo, L.; Pavelic, K.; Pavelc, S.; KarminskiZamolaa, G. Antiproliferative potency of novel benzofuran-2-carboxamides on tumor cell lines: cell death mechanisms and determination of crystal structure. European Journal of Medicinal Chemistry, 2013, 59, 111-119, https://doi.org/10.1016/j.ejmech.2012.11.009.

8. Sato, A.; McNulty, L.; Cox, K.; Kim, S.; Scott, A.; Daniell, K.; Summerville, K.; Price, C.; Hudson, S.; Kiakos, K.; Hartleym J.; Asao, T.; Lee, M. A Novel Class of in Vivo Active Anticancer Agents: Achiral seco-Amino- and secoHydroxycyclopropylbenz[e]indolone (seco-CBI) Analogues of the Duocarmycins and CC-1065. Journal of Medicinal Chemistry 2005, 48, 3903-3918, https://doi.org/10.1021/jm050179u.

9. Królewska-Golińska, K.; Cieślak, M.; Sobczak, M.; Dolot, R.; Radzikowska-Cieciura, E.; Napiórkowska, M.; Wybrańska, I.; Nawrot, B. Novel Benzo[b]Furans with Anti-Microtubule Activity Upregulate Expression of Apoptotic Genes and Arrest Leukemia Cells in G2/M Phase. Anticancer Agents Medicinal Chemistry 2019, 19, 375-388, https://doi.org/10.2174/1871520619666181122123552.

10. Ai, T.; Wilson, D.; More, S.; Xie, J.; Chen, L. 5-((3-Amidobenzyl)oxy)nicotinamides as Sirtuin 2 Inhibitors. Journal of Medicinal Chemistry 2016, 59, 2928-2941, https://doi.org/10.1021/acs.jmedchem.5b01376.

11. Watterson, S.; Liu, C.; Dhar, T.G.; Gu, H.; Pitts, W.; Barrish, J.; Fleener, C.; Rouleau, K.; Sherbina, N.; Hollenbaugh, D.; Iwanowicz, E. Novel amide-based inhibitors of inosine 5'-monophosphate dehydrogenase. Bioorganic \& Medicinal Chemistry Letters 2002, 12, 2879-2882, https://doi.org/10.1016/s0960894x(02)00601-7.

12. Wu, J.; Rush, T.; Hotchandani, R.; Du, X.; Geck, M.; Collins, E.; Xu, Z.; Skotnicki, J.; Levin, L.; Lovering, F. Identification of potent and selective MMP-13 inhibitors. Bioorganic \& Medicinal Chemistry Letters 2005, 15, 4105-4109, https://doi.org/10.1016/j.bmcl.2005.06.019.

13. Saku, O.; Saki, M.; Kurokawa, M.; Ikeda, K.; Takizawa, T.; Uesaka, N. Synthetic studies on selective adenosine A2A receptor antagonists: Synthesis and structure-activity relationships of novel benzofuran derivatives. Bioorganic \& Medicinal Chemistry Letters 2010, 20, 1090-1093, https://doi.org/10.1016/j.bmcl.2009.12.028.

14. Engers, D.; Niswender, C.; Weaver, C.; Usha, S.; N. Menon, U.; Zamorano, R.; Jeffrey, P.; Lindsley, C.; Hopkins, C. Synthesis and Evaluation of a Series of Heterobiarylamides that are Centrally Penetrant Metabotropic Glutamate Receptor 4 (mGluR4) Positive Allosteric Modulators (PAMs). Journal of Medicinal Chemistry 2009, 52, 4115-4118, https://doi.org/10.1021/jm9005065.

15. Choi, M.; Jo, H.; Park, H.; Sateesh, Kumar, A.; Lee, J.; Yun, J.; Kim, Y.; Han, S.; Jung, J.; Cho.; J.; Lee, K.; Kwak, J.; Lee, H. Design, synthesis, and biological evaluation of benzofuran- and 2,3-dihydrobenzofuran2-carboxylic acid $\mathrm{N}$-(substituted)phenylamide derivatives as anticancer agents and inhibitors of NF- $\kappa \mathrm{B}$. Bioorganic \& Medicinal Chemistry Letters, 2015, 25, 2545-2549, https://doi.org/10.1016/j.bmcl.2015.04.050.

16. Chaban, T.I.; Ogurtsov, V.V.; Matiychuk, V.S.; Chaban, I.G.; Demchuk, I.L.; Nektegayev, I.A. Synthesis, anti-inflammatory and antioxidant activities of novel $3 \mathrm{H}$-thiazolo[4,5-b]pyridines. Acta Chimica Slovenica 2019, 66, 103-111, https://doi.org/10.17344/acsi.2018.4570.

17. Pokhodylo, N.T.; Matiychuk, V.S. Synthesis of new 1,2,3-triazolo[1,5-a]quinazolinones. Journal of Heterocyclic Chemistry 2010, 47, 415-420, https://doi.org/10.1002/jhet.321.

18. Obushak, N.D.; Gorak, Yu.I.; Matiichuk, V.S.; Lytvyn, R.Z. Synthesis of heterocycles based on arylation products of unsaturated compounds: XVII. Arylation of 2-acetylfuran and synthesis of 3-R-6-(5-aryl-2furyl)-7H-[1,2,4]triazolo[3,4-b][1,3,4]thiadiazines. Russian Journal of Organic Chemistry 2008, 44, 16891694, https://doi.org/10.1134/S1070428008110213.

19. Chaban, T.; Klenina, O.; Chaban, I.; Ogurtsov, V.; Harkov, S.; Lelyukh, M. Thiazolo[5,4- $d$ ]pyrimidines and thiazolo[4,5-d] pyrimidines: A review on synthesis and Pharmacological importance of their derivatives. Pharmacia 2018, 65, 54-70.

20. Pokhodylo, N.T.; Teslenko, Y.O.; Matiychuk, V.S.; Obushak, M.D. Synthesis of 2,1-benzisoxazoles by nucleophilic substitution of hydrogen in nitroarenes activated by the azole ring. Synthesis 2009, 16, 27412748, https://doi.org/10.1055/s-0029-1216875.

21. Tupys, A.; Kalembkiewicz, J.; Ostapiuk, Y.; Matiichuk, V.; Tymoshuk, O.; Woźnicka, E.; Byczyński, Ł. Synthesis, structural characterization and thermal studies of a novel reagent 1-[(5-benzyl-1,3-thiazol-2- 
yl)diazenyl]naphthalene-2-ol. Journal of Thermal Analysis and Calorimetry 2017, 127, 2233-2242, https://doi.org/10.1007/s10973-016-5784-0.

22. Chaban, Z.; Harkov, S.; Chaban, T.; Klenina, O.; Ogurtsov, V.; Chaban, I. Recent advances in synthesis and biological activity evaluation of condensed thiazoloquinazolines: A review. Pharmacia 2017, 64, 52-66.

23. Zelisko, N.; Atamanyuk, D.; Ostapiuk, Y.; Bryhas, A.; Matiychuk, V.; Gzella, A.; Lesyk, R. Synthesis of fused thiopyrano[2,3- $d][1,3]$ thiazoles via hetero-Diels-Alder reaction related tandem and domino processes. Tetrahedron 2015, 71, 9501-9508, https://doi.org/10.1016/j.tet.2015.10.019.

24. Klenina, O.; Chaban, T.; Zimenkovsky, B.; Harkov, S.; Ogurtsov, V.; Chaban, I.; Myrko, I. Qsar modeling for antioxidant activity of novel $\mathrm{N}^{3}$ substituted 5,7-dimethyl-3H-thiazolo[4,5-b]pyridin-2-ones. Pharmacia 2017, 64, 49-71.

25. Pokhodylo, N.T.; Matiychuk, V.S.; Obushak, N.D. A convenient method for the synthesis of thiopyrano[4,3c]quinoline, a new heterocyclic system. Chemistry of Heterocyclic Compounds 2009, 45, 121-122, https://doi.org/10.1007/s10593-009-0238-2.

26. Chaban, T.; Ogurtsov, V.; Mahlovanyy, A.; Sukhodolska, N.; Chaban, I.; Harkov, S.; Matiychuk, V. Antioxidant properties of some novel derivatives thiazolo[4,5-b]pyridine. Pharmacia 2019, 66, 171-180, https://doi.org/10.3897/pharmacia.66.e36764.

27. Zimenkovskii, B.S.; Kutsyk, R.V.; Lesyk, R.B.; Matyichuk, V.S.; Obushak, N.D.; Klyufinska, T.I. Synthesis and antimicrobial activity of 2,4-dioxothiazolidine-5-acetic acid amides. Pharmaceutical Chemistry Journal 2006, 40, 303-306, https://doi.org/10.1007/s11094-006-0115-6.

28. Pokhodylo, N.T.; Savka, R.D.; Matiichuk, V.S.; Obushak, N.D. Synthesis and selected transformations of 1-(5-methyl-1-aryl-1H-1,2,3-triazol-4-yl)ethanones and 1-[4-(4-R-5-methyl-1H-1,2,3-triazol-1-yl)phenyl] ethanones. Russian Journal of Organic Chemistry 2009, 79, 309-314, https://doi.org/10.1134/S1070363209020248.

29. Chaban, T.; Matiychuk, V.; Ogurtsov, V.; Chaban, I.; Harkov, S.; Nektegaev, I. Synthesis and biological activity of some novel derivatives 5,7-dimethyl-6-phenylazo-3H-thiazolo[4,5-b]pyridine-2-one. Pharmacia 2018, 65, 51-62.

30. Matiichuk, V.S.; Potopnyk, M.A.; Obushak, N.D. Molecular design of pyrazolo[3,4- $d$ ]pyridazines. Russian Journal of Organic Chemistry 2008, 44, 1352-1361, https://doi.org/10.1134/S1070428008090182.

31. Lozynska, L.; Tymoshuk, O.; Chaban, T. Spectrophotometric studies of 4-[n'-(4-imino-2-oxo-thiazolidin-5ylidene)-hydrazino]-benzenesulfonic acid as a reagent for the determination of Palladium. Acta Chimica Slovenica 2015, 62, 159-167, https://doi.org/10.17344/acsi.2014.866.

32. Zubkov, F.I.; Ershova, J.D.; Zaytsev, V.P.; Obushak, M.D.; Matiychuk, V.S.; Sokolova, E.A.; Khrustalev, V.N.; Varlamov, A.V. The first example of an intramolecular Diels-Alder furan (IMDAF) reaction of iminium salts and its application in a short and simple synthesis of the isoindolo[1, 2-a]isoquinoline core of the jamtine and hirsutine alkaloids. Tetrahedron Lett. 2010, 51, 6822-6824, https://doi.org/10.1016/j.tetlet.2010.10.046.

33. Rydchuk, P.V.; Tymoshuk, O.S.; Oleksiv, L.V.; Chaban, T.I.; Matiychuk, V.S. Voltammetric determination of pt(Iv) using 5-hydroxyimino-4-imino-1,3-thiazolidine-2-one. Methods and Objects of Chemical Analysis 2019, 14, 130-139, https://doi.org/10.17721/moca.2019.130-139.

34. Chaban, T.; Ogurtsov, V.; Chaban, I.; Myrko, I.; Harkov, S.; Leluykh, M. Synthesis of some new 4iminothiazolidine-2-ones as possible antioxidants agents. Pharmacia 2019, 66, 27-32, https://doi.org/10.3897/pharmacia.66.e35131.

35. Tymoshuk, O.; Oleksiv, L.; Khvalbota, L.; Chaban, T.; Patsay, I. Spectrophotometric determination of ru(iv) using 5-hydroxyimino-4-imino-1,3-thiazolidin-2-one as a novel analytical reagent. Acta Chimica Slovenica 2019, 66, 62-69, https://doi.org/10.17344/acsi.2018.4448.

36. Pokhodylo, N.T.; Matiychuk, V.S.; Obushak, M.D. Synthesis of ethyl 4,5-disubstituted 2-azido-3thiophenecarboxylates and use in the synthesis of thieno[3,2-e][1,2,3]triazolo[1,5-a]pyrimidin-5(4H)-ones. Tetrahedron 2009, 65, 2678-2683, https://doi.org/10.1016/j.tet.2009.01.086.

37. Chaban, T.; Klenina, O.; Harkov, S.; Ogurtsov, V.; Chaban, I.; Nektegaev I. Synthesis of some new $\mathrm{N}^{3}$ substituted 6-phenylazo-3H-thiazolo[4,5-b]pyridin-2-ones as possible anti-inflammatory agents. Pharmacia 2017, 64, 16-30.

38. Matiichuk, V.S.; Frolov, D.A.; Pokhodylo, N.T.; Pavlyuk, V.V.; Obushak, M.D. Selective Formation of Products of Interrupted Feist-Benary Reaction under the Conditions of Hantzsch Pyrrole Synthesis. Russian Journal of Organic Chemistry 2018, 54, 799-801, https://doi.org/10.1134/S1070428018050238.

39. Bryhas, A.; Horak, Y.; Ostapiuk, Y.; Obushak, M.; Matiychuk, V.S. A new three-step domino Knoevenagelhetero-Diels-Alder oxidation reaction. Tetrahedron Letters 2011, 52, 2324-2326, https://doi.org/10.1016/j.tetlet.2011.02.081.

40. Finiuk, N.S.; Ivasechko, I.; Klyuchivska, O.; Ostapiuk, Y.V.; Hreniukh, V.P.; Shalai, Y.R.; Matiychuk, V. S.; Obushak, M.D.; Stoika, R.S.; Babsky, A.M. Apoptosis induction in human leukemia cells by novel 2amino-5-benzylthiazole derivatives. Ukrainian Biochemical Journal 2019, 91, 29-39. https://doi.org/10.15407/ubj91.02.029. 
41. Batsyts, S.; Shehedyn, M.; Goreshnik, E.A.; Obushak, M. D.; Schmidt, A.; Ostapiuk, Y.V. 2-Bromo-2chloro-3-arylpropanenitriles as C-3 Synthons for the Synthesis of Functionalized 3-Aminothiophenes. European Journal of Organic Chemistry 2019, 28, 7842-7856, https://doi.org/10.1002/ejoc.201901512.

42. Sulyma, M.; Vasyuk, S.; Zhuk, Y.; Kaminskyy, D.; Chupashko, O., Ogurtsov, V. New spectrophotometric method of amlodipine besylate determination and its validation. Chemistry and Chemical Technology 2018, 12, 429-433.

43. Chaban, T.; Matiychuk, V.; Mahlovanyy, A.; Chaban, I.; Ogurtsov, V.; Lelyukh, M. Antitumor properties of thiazolo[4,5-b]pyridin-2-one derivatives. Biointerface Research in Applied Chemistry 2020, 10 (4), 59445950. https://doi.org/10.33263/BRIAC104.944950.

44. Matiichuk, Y.; Ogurtsov, V.; Ostapiuk, Y.; Chaban, T.; Matiychuk, V. Synthesis, anti-inflammatory activity and molecular docking of 2-methyl-3-furamides Biointerface Research in Applied Chemistry 2020, 10 (4), 5809-5814. https://doi.org/10.33263/BRIAC104.809814.

45. Tymoshuk, O.; Oleksiv, L.; Rydchuk, P.; Chaban, T.; Tymoshuk, S.; Matiychuk, V. Spectrophotometric Study of the Interaction of Platinum(IV) with New Derivatives of Azolidones. Chemistry and Chemical Technology 2020, 14, 139-145, https://doi.org/10.23939/chcht14.02.

46. Finiuk, N.; Klyuchivska, O.; Ivasechko, I.; Hreniukh, V.P.; Ostapiuk, Y.V.; Shalai, Ya. R.; Panchuk, R. R.; Matiychuk, V. S.; Obushak, M. D.; Stoika, R., Babsky, A. Proapoptotic Effects of Novel Thiazole Derivative on Human Glioma Cells. Anticancer Drugs 2019, 30, 27-37, https://doi.org/10.1097/CAD.0000000000000686.

47. Obushak, M.D.; Matiychuk, V.S.; Turytsya, V.V. A new approach to the synthesis of 3,4dihydroisocoumarin derivatives Tetrahedron Letters 2009, 50, 6112-6115, https://doi.org/10.1016/j.tetlet.2009.08.024.

48. Bazel, Y.; Tupys, A.,; Ostapiuk, Y.; Tymoshuk, O.; Imrich, J.; Sandrejova, J. A simple non-extractive green method for the spectrophotometric sequential injection determination of copper(ii) with novel thiazolylazo dyes. RSC Advances 2018, 8, 15940-15950, https://doi.org/10.1039/C8RA02039F.

49. Pokhodylo, N.T.; Matiychuk, V.S.; Obushak, M.D. Synthesis of triazoles via regioselective reactions of aryl azides with cyanoacetyl pyrroles and indoles. Synthesis 2009, 8, 1297-1300, https://doi.org/10.1055/s-00281087992.

50. Finiuk, N.S.; Ostapiuk, Y.V.; Hreniukh, V.P.; Shalai, Y.R.; Matiychuk, V.S.; Obushak, M. D.; Stoika, R.S.; Babsky, A.M. Evaluation of antiproliferative activity of pyrazolothiazolopyrimidine derivatives. Ukrainian Biochemical Journal 2018, 90, 25-32. https://doi.org/10.15407/ubj90.02.025.

51. Lelyukh, M.; Adamchuk, S.; Harkov, S.; Chaban I.; Shelepeten, L., Chaban T. Synthetic approaches, chemical modification and biological activity of non-condensed 1,3,4-thiadiazole derivatives: A review. Pharmacia 2018, 65, 72-88.

52. Bazel, Y.; Tupys, A.; Ostapiuk, Y.; Tymoshuk, O.; Matiychuk, V. A green cloud-point microextraction method for spectrophotometric determination of $\mathrm{Ni}(\mathrm{II})$ ions with 1-[(5-benzyl-1,3-thiazol-2yl)diazenyl]naphthalene-2-ol. Journal of Molecular Liquids 2017, 242, 471-477, https://doi.org/10.1016/j.molliq.2017.07.047.

53. Chaban, T.I.; Matiychuk, V.S.; Ogurtsov, V.V.; Chaban, I.G.; Nektegayev, I.A. Development of effective anti-inflammatory drug candidates among novel thiazolopyridines. Ukrainian Biochemical Journal 2020, 92, 132-139, https://doi.org/10.15407/ubj92.02.132.

54. Ostapiuk, Y.V.; Frolov, D.A.; Vasylyschyn, R.Y.; Matiychuk, V.S. Synthesis and antitumor activities of new n-(5-benzylthiazol-2-yl)-2-(heteryl-5-ylsulfanyl)-acetamides. Biopolymers and Cell 2018, 34, 59-71, http://doi.org/10.7124/bc.000971.

55. Shyyka, O.; Pokhodylo, N.; Finiuk, N.; Matiychuk, V.; Stoika, R.; Obushak, M. Anticancer activity evaluation of new thieno[2,3- $d$ ]pyrimidin-4(3H)-ones and thieno[3,2- $d$ ]pyrimidin-4(3H)-one derivatives. Scientia Pharmaceutica 2018, 86, 28-32, https://doi.org/10.3390/scipharm86030028.

56. Obushak, N.D.; Matiichuk, V.S.; Vasylyshin, R.Y.; Ostapyuk, Y.V. Heterocyclic syntheses on the basis of arylation products of unsaturated compounds: X. 3-aryl-2-chloropropanals as reagents for the synthesis of 2-amino-1,3-thiazole derivatives. Russian Journal of Organic Chemistry 2004, 40, 383-389, https://doi.org/10.1023/B:RUJO.0000034976.75646.85.

57. Obushak, N.D.; Lesyuk, A.I.; Gorak, Y.I.; Matiichuk, V.S. Mechanism of Meerwein arylation of furan derivatives. Russian Journal of Organic Chemistry 2009, 45, 1375-1381, https://doi.org/10.1134/S1070428009090103.

58. Gorak, Yu.I.; Obushak, N.D.; Matiichuk, V.S.; Lytvyn, R.Z. Synthesis of heterocycles from arylation products of unsaturated compounds: XVIII. 5-Arylfuran-2-carboxylic acids and their application in the synthesis of 1,2,4-thiadiazole, 1,3,4-oxadiazole, and [1,2,4]triazolo[3,4- $b][1,3,4]$ thiadiazole derivatives. Rus. J. Org. Chem. 2009, 45, 541-550, https://doi.org/10.1134/S1070428009040125.

59. Developmental Therapeutics Program 01 may 2020. Available online: http://dtp.nci.nih.gov.

60. Monks, A.; Scudiero, D.; Skehan, P.; Shoemaker, R.; Paull, K.; Vistica, D.; Hose, C.; Langley, J.; Cronise, P.; Vaigro-Wolff A. Feasibility of a high-flux anticancer drug screen using a diverse panel of cultured human tumor cell lines. J. Nat. Cancer Inst. 1991, 83, 757-766, https://doi.org/10.1093/jnci/83.11.757. 
61. NasserAl-Romaizan, A. Synthesis and antitumor activity of new isolated and fused heterobicyclic nitrogen systems containing 1,3,4-thiadiazole moiety derived from N1,N2-diaryl hydrazine compound. Letters in Applied NanoBioScience 2020, 9 (1), 885-891. https://doi.org/10.33263/LIANBS91.885891.

62. Boyd, M.R.; Paull, K.D. Some practical considerations and applications of the National Cancer Institute in vitro anticancer drug discovery screen. Drug Dev. Res. 1995, 34, 91-109, https://doi.org/10.1002/ddr.430340203.

63. Shoemaker, R.H. The NCI60 human tumour cell line anticancer drug screen. Nat. Rev. Cancer 2006, 6, 813823, https://doi.org/10.1038/nrc1951. 